\title{
PENYULUHAN BAHAYA ROKOK UNTUK MENINGKATKAN KESADARAN REMAJA MENGENAI DAMPAK BURUK ROKOK BAGI KESEHATAN DI SMP TAWWAKAL DENPASAR
}

\author{
Diah Prihatiningsih, Ni Luh Putu Devhy, Ika Setya Purwanti, \\ Ni Wayan Desi Bintari, AA Gde Oka Widana \\ STIKes Wira Medika Bali \\ Email: diahciprik@gmail.com
}

\begin{abstract}
ABSTRAK
Rokok merupakan salah satu faktor resiko utama dari beberapa penyakit kronis yang dapat mengakibatkan kematian. Hal ini menunjukkan bahwa rokok merupakan masalah besar bagi kesehatan masyarakat. Selain dari segi kesehatan, rokok juga mempengaruhi kepribadian perokok itu sendiri. Biasanya remaja usia SMP sudah mengenalrokok. Menurut mereka, kalau tidak merokok maka mereka dianggap tidak gaul. Semua hal tersebut belum sepenuhnya dipahami oleh remaja yang aktifitas merokok bahkan menjadi salah satu budaya dalam sosial mereka. Kegiatan pengadian masyarakat di SMP Tawakkal ini bertujuan untuk meningkatkan kesadaran siswa mengenai dampak buruk rokok bagi kesehatan. Peserta pengabdian masyarakat merupakan siswa sekolah menengah pertama kelas 8 yang berjumlah 64 anak. Berdasarkan jenis kelamin, peserta pengabdian terdiri atas 34 siswa laki-laki (53,13\%) dan 30 siswa perempuan (46,87\%). Kegiatan ini diawali dengan pengisian kuisioner pre-test pengetahuan tentang bahaya rokok yang kemudian dilanjutkan dengan penyuluhan oleh narasumber dan dilakukan kembali pengisian kuisioner posttest. Hasil dari pengisian kuisioner setelah dilakukan penyuluhan mengalami peningkatan yaitu sebesar 92,89\% siswa memahami tentang dampak buruk akibat rokok. Selama melakukan penyuluhan siswa sangat antusias dalam mendengarkan pemateri, untuk itu diharapkan kegiatan ini digalakkan khususnya di dunia Pendidikan.
\end{abstract}

Kata kunci : Rokok, Remaja, Kesehatan

\begin{abstract}
Smoking is one of the main risk factors of several chronic diseases that can result in death. This shows that smoking is a big problem for public health. Apart from the health aspect, smoking also affects the personality of the smoker himself. Usually middle school age teenagers already know cigarettes. According to them, if they don't smoke, they are considered to be not slang. All these things have not been fully understood by adolescents whose smoking activities even become one of their social culture. The community outreach activity at SMP Tawakkal aims to increase student awareness about the adverse effects of smoking on health. The participants were $8^{\text {th }}$ grade junior high school students, totaling are 64 childrens. Based on gender, the participants consisted of 34 male students $(53,13 \%)$ and 30 female students (46,87\%). This activity began with the filling of a pre-test
\end{abstract}


questionnaire of knowledge about the dangers of smoking which was then followed by counseling by the informants and carried out a post-test questionnaire filling again. The results of filling out th questionnaire after counseling has increased by $92,89 \%$ of students understanding about the adverse effects of smoking. During the counseling the students were very enthusiastic in listening to the speakers, so it was hoped that this activity would be encouraged especially in the world of education.

Keywords : Smoking, Teenagers, Health 


\section{PENDAHULUAN}

Rokok merupakan salah satu faktor resiko utama dari beberapa penyakit kronis yang dapat mengakibatkan kematian. Banyak penelitian sudah membuktikan bahwa merokok dapat meningkatkan resiko timbulnya berbagai penyakit yang dapat mengakibatkan kematian. Hal ini menunjukkan bahwa rokok merupakan masalah besar bagi kesehatan masyarakat. Selain dari segi kesehatan, rokok juga mempengaruhi kepribadian perokok itu sendiri. Biasanya remaja usia SMP sudah mengenal rokok. Menurut mereka, kalau tidak merokok maka mereka dianggap tidak gaul. Sehingga banyak anak usia sekolah dengan santainya mereka merokok di luar sekolah dengan masih memakai seragam sekolah[1]. Mereka tidak memperdulikan akibat dari rokok walaupun sudah banyak iklan-iklan yang menyampaikan bahwa merokok itu dilarang. Untuk itu sebaiknya kampanye anti rokok dilaksanakan sejak dini di sekolah-sekolah.

Kegiatan razia mengenai anti rokok di sekolah-sekolah harus digalakkan. Hal ini dikarenakan bahwa remaja merupakan tulang punggung bangsa yang bisa mempelopori gerakan hidup sehat dengan anti rokok. Manusia memiliki banyak sekali kebiasaan. Akan tetapi salah satu kebiasaan yang paling sulit dihilangkan adalah kebiasaan merokok dan kebiasaan tersebut jarang sekali diakui orang sebagai suatu kebiasaan buruk. Apalagi orang yang merokok untuk mengalihkan diri dari stress dan tekanan emosi, lebih sulit melepaskan diri dari kebiasaan ini dibandingkan perokok yang tidak memiliki latar belakang depresi.

Masa remaja merupakan masa dimana seorang individu mengalami peralihan dari satu tahap ketahap berikutnya dan mengalami perubahan baik emosi, tubuh, minat pola perilaku, dan juga penuh dengan masalahmasalah. Para remaja sekarang sering kali menganggap enteng dengan kesehatan mereka[2]. Mereka hanya memikirkan apa yang akan membuat mereka senang, seperti rokok. Remaja cenderung memiliki rasa ingin tahu yang besar. Karena masa remaja adalah masa dimana seseorang masih 
mencari jati dirinya dan labil terutama terhadap pengaruh lingkungan. Remaja merupakan masa dimana seorang individu mengalami peralihan dari satu tahap ketahap berikutnya dan mengalami perubahan baik emosi, tubuh, minat, polaperilaku, dan juga penuh dengan masalah-masalah[3].

Berdasarkan laporan Badan Kesehatan Dunia (WHO) tahun 1999, sekitar 250 juta anak-anak di dunia akan meninggal apabila konsumsi tembakau tidak dihentikan secepatnya. Kebiasaan merokok bagi para pelajar bermula karena kurangnya informasi dan kesalahpahaman informasi, termakan iklan atau terbujuk rayuan teman. Menurut hasil angket Yayasan Jantung Indonesia sebanyak 77\% siswa merokok karena ditawari teman,pergaulan diluar rumah juga menjadi hal yang punya pengaruh besar terhadap perkambangan seorang remaja. Sudah sering dijumpai bahwa remaja akani kut-ikutan merokok ketika ada seorang teman yang menawari barang berbahaya itu padanya. Bahkan lebih miris, jika banyak remaja beranggapan merekaakan terlihat lebih keren atau lebih gaul jika mengkonsumsi rokok.

Konsumsi rokok di Indonesia mencapai 215 miliyar batang per tahunnya. Di Indonesia ada 60\% perokok, 59\% diantaranya adalah lakilaki dan $37 \%$ nya perempuan. Di Indonesia tembakau ditambah cengkeh dan bahan-bahan lain dicampur untuk dibuat rokok kretek. Selain kretek tembakau juga dapat digunakan sebagai rokok linting,rokok putih, cerutu, rokok pipa dan tambakau tanpa asap (tembakaukunyah), silinder dari kertas berukuran panjang antara 70-120 mm dengan diameter $10 \mathrm{~mm}$ yang berisi daun-daun tembakau yang telah dicacah. Rokok dibakar disalah satu ujungnya dan dibiarkan membara agar asapnya dihirup melalui mulut pada ujung lain. Bahan dasar rokok adalah tembakau. Tembakau terdiri dari berbagai bahan kimia yang dapat membuat seseorang ketagihan, walaupun mereka tidak ingin mencobanya lagi. Beberapa bahan bahkan begitu beracun sehingga beberapa pabrik "rokok" besar biasanya akan memiliki standar yang tinggi untuk membuang bahan-bahan beracun yang sangat berbahaya tersebut, 
jumlah perokok di Indonesia menduduki peringkat ketiga tertinggi didunia. Jumlah perokok di negara-negara berkembang jauh lebih banyak disbanding jumlah perokok di negara maju.

Semua hal tersebut belum sepenuhnya dipahami oleh remaja yang aktifitas merokok bahkan menjadi salah satu budaya dalam social mereka. Seperti ketika mereka berkumpul hanya untuk sekedar nongkrong biasanya ada saja yang merokok. Untuk itu sangatlah penting dilakukan penyuluhan mengenai bahaya rokok bagi kesehatan guna memberikan edukasi bagi Remaja di SMP Tawwakal Denpasar.

\section{METODE PELAKSANAAN}

Kegiatan pengabdian kepada masyarakat dilaksanakan di SMP Tawwakal Denpasar yang beralamat di Jalan Raya Puputan No. 54 Dangin Puri Klod Denpasar Timur. Kegiatan yang dilakukan meliputi tiga tahap yaitu tahap perencanaan, tahap pelaksanaan, dan tahap evaluasi. Tahap perencanaan dimulai dengan mencari informasi mengenai rokok melalui jurnal, artikel penelitian atau pengabdian masyarakat serupa. Selanjutnya dilakukan observasi sederhana pada siswa menengah pertama. Berdasarkan observasi dan studi pustaka dari berbagai sumber selanjutnya diidentifikasi permasalahan-permasalahan yang terjadi pada siswa sekolah menengah pertama khususnya pengetahuan mengenai rokok. Selanjutnya dilakukan perumusan kiat dan langkah yang bisa dilakukan.

Pelaksanaan kegiatan pengabdian masyarakat ini dilakukan dengan cara melakukan observasi kepada siswa siswi SMP Tawakal mengenai pengetahuan mereka tentang rokok. Selanjutnya dilakukan penyuluhan tentang bahaya rokok terhadap remaja oleh narasumber yang berasal dari SATGAS KTR. Penyuluhan ini dilakukan dengan metode ceramah.

Tahap evaluasi meliputi evaluasi perencanaan dan evaluasi acara. Evaluasi perencanaan bertujuan untuk menilai apakah persiapan kegiatan pengabdian masyarakat sudah optimal atau tidak. Tahap evaluasi acara 
bertujuan untuk menilai target acara terpenuhi atau tidak dengan item evaluasi meliputi ketepatan waktu, keteraturan acara, jumlah peserta, daya tarik peserta terhadap penjelasan pembicara dan ketanggapan panitia.

\section{HASIL DAN PEMBAHASAN}

Kegiatan pengabdian masyarakat dilaksanakan pada tanggal05-07 Agustus 2019 yang berlokasi di SMP Tawakkal. Peserta pengabdian masyarakat merupakan siswa sekolah menengahpertamakelas 8 yang berjumlah 64 anak. Berdasarkan jenis kelamin, peserta pengabdian terdiri atas 34 siswa laki-laki $(53,13 \%)$ dan 30 siswa perempuan $(46,87 \%)$. Berdasarkan kelompok usia peserta merupakan anak-anak dengan usia 14 tahun di tahun 2019.

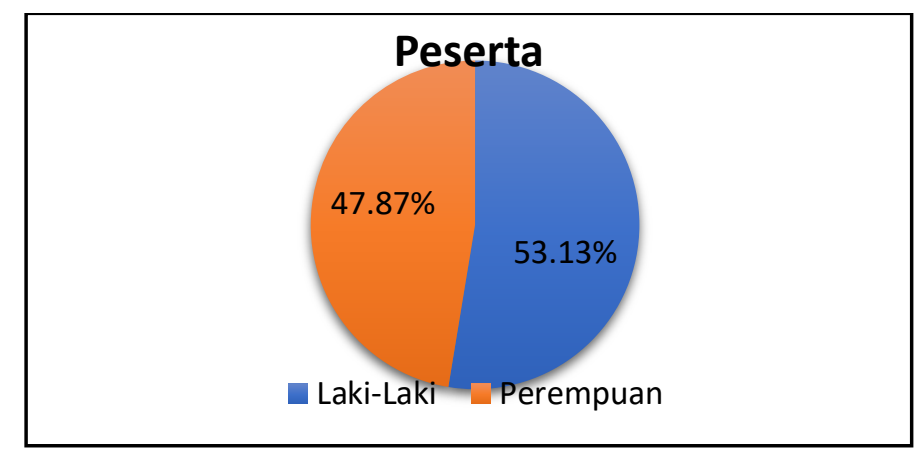

Gambar 1. Karakteristik jenis kelamin peserta penyuluhan

Kegiatan pengabdian masyarakat diawali dengan mengisi kuisioner tentang pengetahuan anak-anak mengenai bahaya dan akibat rokok. Kuisioner ini bertujuan untuk mengetahui seberapa besar pengetahuan yang dimiliki oleh anak-anak kelas 8 di SMP Tawakal mengenai bahaya akibat rokok. Selanjutnya dilakukan sosialisasi langsung oleh narasumber yang berasal dari UniversitasUdayana. Narasumber mensosialisasikan mengenai bahaya rokok bagi remaja. Selanjutnya setelah sosialisasi berlangsung maka dibagikan kembali kuisioner untuk mengetahui seberapa pengetahuan yang tadi telah disampaikan tadi terserap oleh mereka. 
Berdasarkan hasil kuisioner pre-test terhadap tingkat pengetahuan siswa mengenai bahaya akibat rokok diketahui sebesar 45,34\% siswa tidak mengetahui bahaya akibat rokok dan $54,66 \%$ siswa mengetahui akibat bahaya rokok.

Penyuluhan yang dilakukan oleh pemateri ini diikuti dengan sangat antusias oleh semua siswa. Materi penyuluhan yang diberikan secara umum lebih difokuskan kepada rokok itu sendiri, kandungan dari rokok, dampak dari penggunaan rokok, perokok pasif dan aktif, serta penyakit apa yang diakibatkan oleh rokok. Siswa dianjurkan untuk menjauhi rokok. Mereka ditekankan terhadap faktor-faktor resiko yang akan terjadi jika mereka merokok. Banyak siswa yang mengajukan pertanyaan yang terkait dengan rokok.

Berdasarkan kuisioner post-test yang dilakukan setelah pemateri melakukan penyuluhan tentang bahaya rokok maka didapatkan peningkatan pengetahun tentang bahaya rokok. Dimana 92,89\% siswa sudah sadar akan bahaya yang dapat ditimbulkan akibat merokok, sedangkan $7,11 \%$ masih belum memahami bahaya yang dapat ditimbulkan akibat dari merokok.

Meskipun penyuluhan terkait bahaya rokok sudah banyak dilakukan tetapi penyuluhan-penyuluhan seperti ini masihharus digalakkan di dunia Pendidikan. Kegiatan ini meningkatkan pemahaman siswa tentang dampak merokok bagi tubuh beserta bahayanya dan memberikan hasil sebagai berikut :

- Peningkatan pengetahuan siswa tentang bahaya rokok bagi dirinya sendiri ataupun orang lain.

- Mencegah siswa yang tidak memiliki kebiasaan atau mencoba rokok untuk tidak merokok, untuk yang sudah mulai mencoba rokok untuk berhenti merokok atau menghindari kebiasaan merokok. 
- Para siswa SMP Tawakal diharapkan dapat menularkan ilmu pengetahuan tentang bahaya rokok yang dimiliki ke orang-orang disekitarnya.

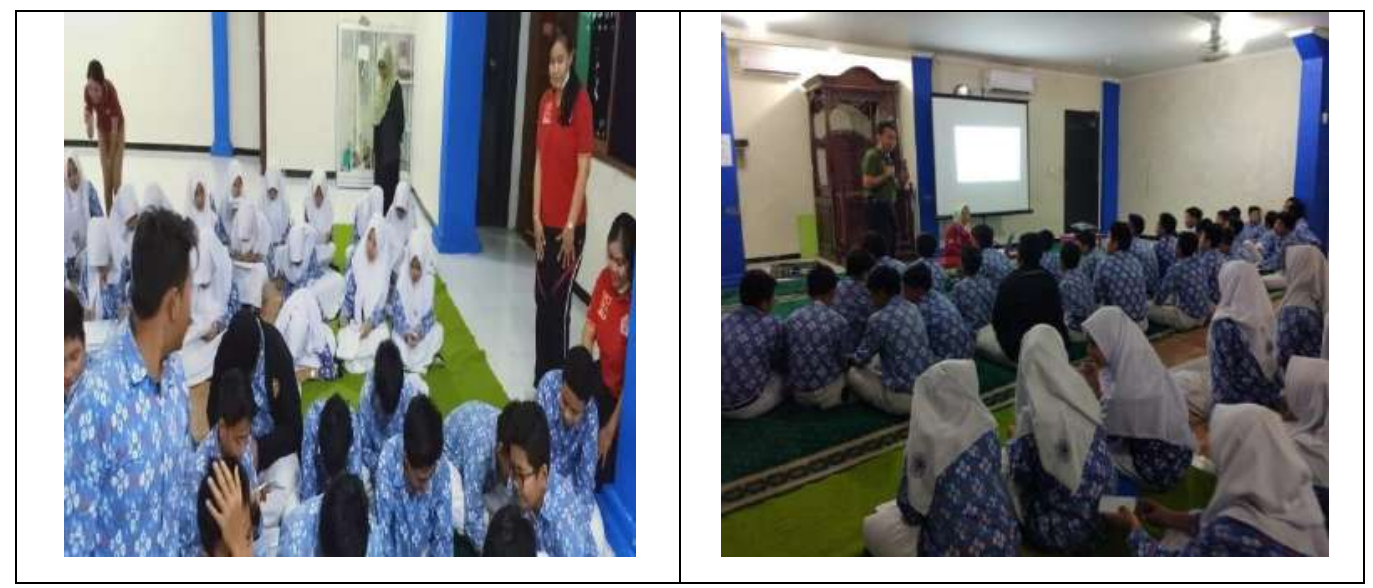

Gambar 2. Proses Pengisian Kuisioner dan Pemberian Materi

\section{SIMPULAN DAN SARAN}

\section{Simpulan}

1. Peserta penyuluhan bahaya rokok guna meningkatkan kesadaran remaja akan besarnya dampak buruk rokok bagi kesehatan yaitu siswa kelas 8 SMP Tawakal yang terdiri dari 64 anak, 34 anak laki-laki dan 30 anak perempuan.

2. Penyuluhan terkait bahaya rokok guna meningkatkan kesadaran remajaakan besarnya dampak buruk rokok bagi kesehatan diikuti dengan baik oleh siswa dan seluruh siswa mendengarkan penyuluhan secara tertib.

3. Penyuluhan yang dilakukan meningkatkan kesadaran siswa tentang bahaya rokok yaitu sebesar $92,89 \%$ siswa mengetahui dampak akibat merokok. 


\section{Saran}

Kegiatan pengabdian masyarakat di SMP Tawakkal Denpasar mengenai penyuluhan tentang bahaya rokok untuk meningkatkan kesadaran remaja akan dampak buruk dari rokok harus ditegakkan pelaksanaannya khususnya di dunia pendidikan. Agar kegiatan ini tersosialisasi dengan baik.

\section{DAFTAR PUSTAKA}

1. Nasution. 2013. Perilaku Merokok Pada Remaja. Medan: Universitas Sumatera Utara Press.

2. Heryani. 2014. Perubahan Perilaku Remaja. Jurnal Article.(http://jurnal.usu.repository.com.diakses)

3. Yusuf, S. 2012. Psikologi Perkembangan Anak dan Remaja (Edisi Revisi). Bandung: PT. Remaja Rosda karya. 